\title{
Rock. Fire. Blood. And, media reaction: A case study of the 2018 riot in Binh Thuan Province, Vietnam
}

\author{
Ho Manh Tung ${ }^{1}$ \\ ${ }^{1}$ Ritsumeikan Asia Pacific University, Beppu City, Oita Prefecture, Japan
}

\begin{abstract}
:
In June 2018, the news of the violent riot that happened in Binh Thuan, the province on the southeastern coast of Vietnam, shook up the domestic media. This paper attempts to understand the media coverage of the event under the lens of the theories of mediatization, connective turn, mediality, and witnessing. First, it will explore the propaganda and anti-propaganda that take place in the Vietnamese state media and the foreign-based Vietnamese media outlets. The paper then employs these concepts to analyze how the state is mediatized, and how citizen journalism together with social media influence and challenge the narrative on both sides of the media. The paper suggests a consistent ideology is on display in both sides of the media and the patterns in which the media report this kind of unusual socio-political events are unlikely to change.
\end{abstract}

\section{Keywords:}

Vietnam, the Binh Thuan riot, mediality, propaganda, mediatization, social media

"Mediatization refers to a long-process, whereby social and cultural institutions and modes of interaction are changed because of growing media's influence."

- Hjarvard (2008)

\section{Introduction}

In the evening of June $10^{\text {th }} 2018$, a crowd gathered in front of the People's Council in the southern Vietnamese province of Binh Thuan to protest against the controversial draft law on special economic-administrative zones (SEAZs), which, if passed, would allow lands in these zones to be leased up to 99 years to foreign investors. The riots soon broke out in many key governments buildings in the city such as the Department of Planning and Investment and the Department of Fire Fighting. People took to the street and blocked the national route of this city.

To understand the riot, it is important to highlight the socio-political context. During this time, Vietnam's National Assembly was scheduled to pass two controversial laws: the SEAZs law and the cybersecurity law. Before that, the revisions of the Vietnamese land law in particular and the economic reform in 1986, in general, have been considered as an expression of the entrepreneurial spirit of the government, which ultimately resulted in the fast development of the economy (Vuong, 2014; Vuong \& Tran, 2009). However, the land has been a major source of 
conflicts since then (Hayton, 2010). The Binh Thuan riot was mostly characterized by the fear of Chinese expansionism (Sands, 2018). In Binh Thuan, Chinese investors hold a 95\% stake of a power plant called Vinh Tan, which is known for polluting the environment and causing problems with the people in the neighborhood (Luong-Bang, 2018; Panda \& Parameswaran, 2018; RFA, 2015).

This essay will cover two perspectives: the Vietnamese state-owned media and the Vietnamese foreign media. Both are in the Vietnamese language, but the foreign-based media outlets are known for carrying an anti-communist tone, which stands against the current regime's. The three most popular sites are BBC Vietnamese (UK-Based), Voice of America (U.S.-based) and Radio Free Asia (France-based), while the others include nguoi-viet.com, Saigon Broadcasting TV network. In Vietnamese state media, these news outlets are often characterized as "reactionary sites," or even "terrorist sites," and people are warned about their anti-state and anti-party content. Nonetheless, given that Vietnam does not enforce a great firewall, the nonstate media outlets remain accessible most of the time.

\section{The propaganda and the anti-propaganda}

In this section, we will look at the propaganda that takes place on each side of the media. This information war shows the irony that although the Vietnamese state is very forthright about its propaganda (one of its key departments is the Central Propaganda and Training Commission, tasked with promoting the Party and State's policies and visions (CPV, 2018)), propaganda is not only reserved to the state media.

First of all, let's take a look at the images of the riot that were shown on both sides of the media. Figure 1 shows the images broadcast by the state media. It seems that the state media tried only to highlight the extent of the damage caused by the riot (the burnt building in Figure 1a) and how violent the crowd became (Figure 1b).

Figure 1: Figures of the event reported by Vietnamese state media. (a) The firefighter police building was burnt after the riot; (b) People broke in and used gas bombs to set fire to a government building (PhuongNghi, 2018). 

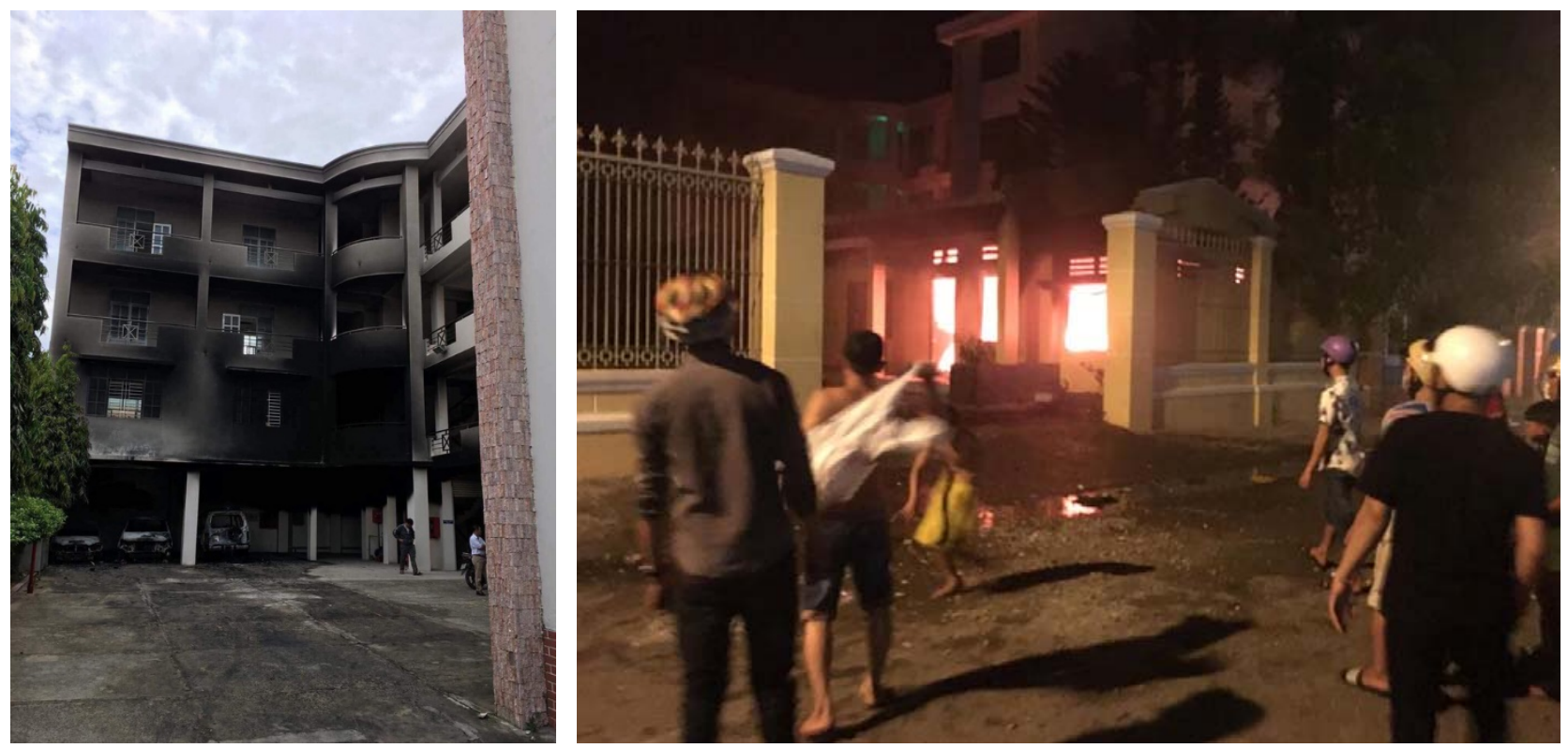

On the other hand, Figure 2 shows how the foreign media highlighted the weakness and incompetence of the police, and by extension, the overwhelming force of the people (Figure 2a), any injury inflicted on the people during the clash (Figure 2b), and the opposition or the schism between the police (the state) and the people (Figure 2c).

Figure 2: Figures of the event reported by the foreign media. (a) The police ran away as the force of the crowd was overwhelming (BBC Vietnamese, 2018); (b) An old man was beaten by the state police (Nguoi-Viet, 2018); (c) The stand-off between the state police and the people on the central route near Binh Thuan Province (VOA Vietnamese, 2018). 

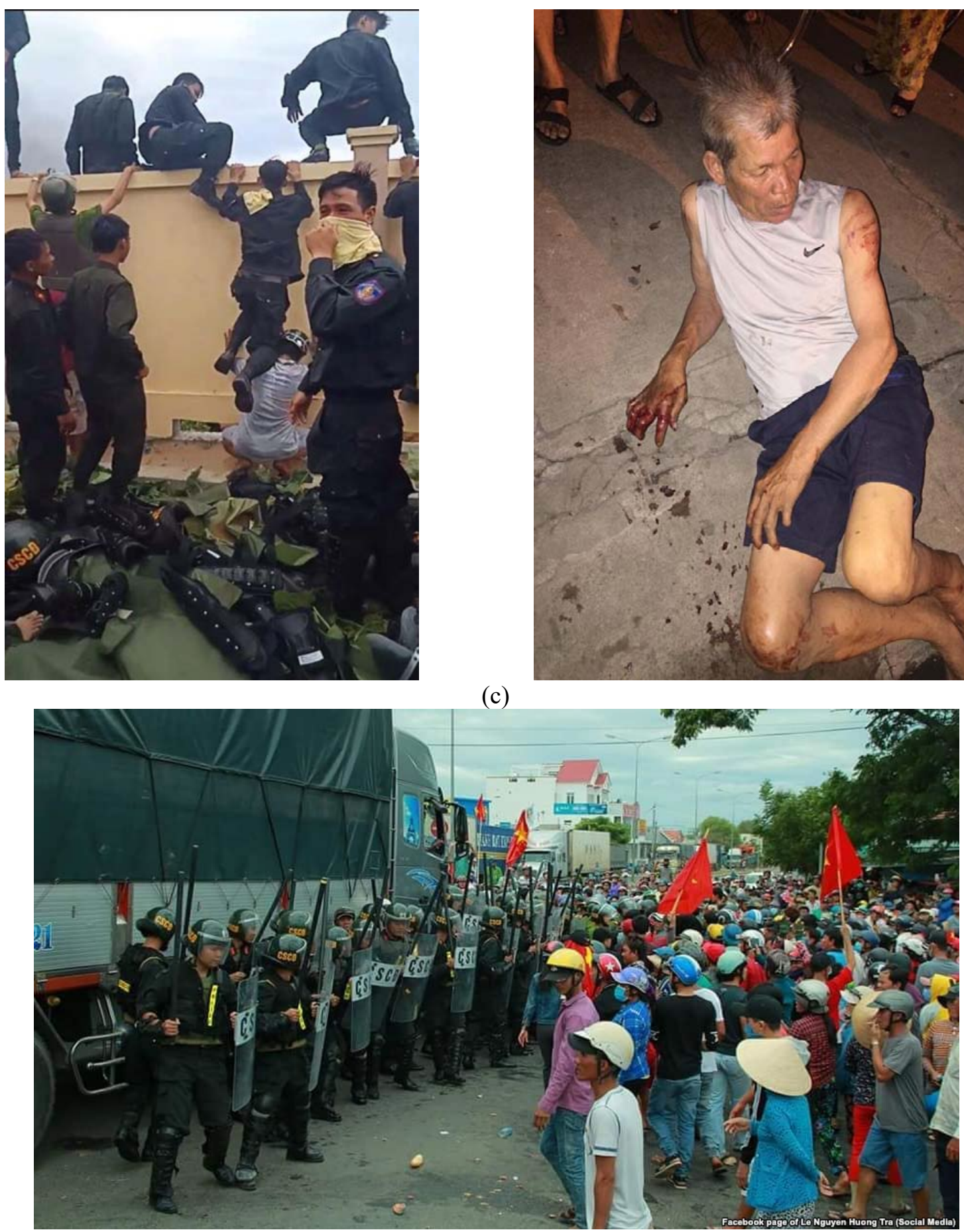

One of the interesting aspects of this event is that most of the images were taken and posted first on the Facebook pages of individuals who tried to live broadcast the riot (BBC Vietnamese, 2018). The role of these citizen journalists will be studied subsequently.

In Table 1, the discourses on both sides of the media are examined. The propaganda on each side is opposed. For example, the state media attributed the cause of the riot to a third party, 
the "hostile forces" or "hostile elements" and the people's patriotism was taken advantages of. In contrast, the foreign media portrayed the riot as a ground-up and spontaneous reaction of the people against actions of the regime. In terms of the state's responses to the incident, the foreign media focused on the "evil" acts of the regime, accusing the regime of cruelly attacking patriotic protestors and forcing confessions on them. Meanwhile, the state media focused on warning the people not to join the protests through all possible means: radio, mobile phone text messages, loud local speakers, and word of mouth of the neighbors. The state media also tried to delegitimize the riot by showing in national television and newspapers that many of the suspects admitted they were drug addicts and received money to rile up the people.

Table 1: Different ways in which the riot is described in Vietnamese state media and foreign media

\begin{tabular}{|c|c|c|}
\hline $\begin{array}{l}\text { Description of } \\
\text { the events }\end{array}$ & Vietnamese state media & Vietnamese foreign media \\
\hline Characterization & $\begin{array}{l}\text { - The riot was caused by individuals } \\
\text { who are provoked and enticed by the } \\
\text { "hostiles elements." } \\
\text { - Many people who started the riot are } \\
\text { addicts and received money to do it. } \\
\text { - Patriotism is taken advantages of. }\end{array}$ & $\begin{array}{l}\text { - The riot was caused because the } \\
\text { people were angry with the } \\
\text { government selling Vietnamese } \\
\text { lands to the Chinese. } \\
\text { - The communist regime did not listen } \\
\text { to the wishes of the people. Its day is } \\
\text { coming. }\end{array}$ \\
\hline Timeline & $\begin{array}{l}\text { - June } 10^{\text {th }}: \text { the riot broke out. } \\
\text { - June } 11^{\text {th }} \text { : the riot was basically } \\
\text { contained. }\end{array}$ & $\begin{array}{l}\text { - June } 10^{\text {th }}: \text { the riot broke out. } \\
\text { - June } 11^{\text {th }}: \text { the state police ran away. }\end{array}$ \\
\hline $\begin{array}{l}\text { State responses } \\
\text { reported }\end{array}$ & $\begin{array}{l}\text { - Warning statements issued through } \\
\text { radio, SMS text messages, loud local } \\
\text { speakers. } \\
\text { - Arrested } 102 \text { suspects, kept eight after } \\
\text { interrogation. } \\
\text { - The state decided to delay the date of } \\
\text { the passing the law on SEZs and } \\
\text { called for calmness. } \\
\text { - These eight perpetrators are } \\
\text { prosecuted. }\end{array}$ & $\begin{array}{l}\text { - People captured illegally, forced } \\
\text { confessions, tortured, and beaten. } \\
\text { - The state decided to delay the date of } \\
\text { the passing the law on SEZs and } \\
\text { called for calmness. } \\
\text { - These eight perpetrators are jailed. }\end{array}$ \\
\hline $\begin{array}{l}\text { Number } \\
\text { causalities }\end{array}$ & $\begin{array}{l}\text { - Ten cars burnt, central route blocked } \\
\text { for several days, } 30 \text { police injured, no } \\
\text { dead. }\end{array}$ & $\begin{array}{l}\text { - People are beaten and injured. There } \\
\text { are polices dead. }\end{array}$ \\
\hline
\end{tabular}

Although there is no definite victory claimed by any side, it is clear the riot in Binh Thuan, and its inspired protests in other provinces seem to have resulted in something tangible: the state decided to delay the date of passing the law on SEAZs (Panda \& Parameswaran, 2018).

\section{The role of citizen journalism and social media}

As noted above, interestingly, most of the images and videos used by both sides of the media were from citizen journalists, those who recorded the events and posted them with their interpretations on their Facebook accounts. Here, the concepts of the connective turn, witness, and mediality are relevant to the discussion. 
In War and Media, Hoskins and O'Loughlin (2010) argue that "the connective turn of the digital transforms the photographs from a discrete object to a node (or many nodes) in a network" (p. 25). In the riot of Binh Thuan province, the narrative of the foreign media on the cruelty of the state police was later challenged or at least recontextualized by the videos posted on Youtube and Facebook (the video got 7,400 reactions and 1,100 shares), in which the police force seems to be disciplined and hold on to their ground under the constant stone attacks of a provoked and unhinged mob. Here, all the images shown in Figures 1 and 2 cannot be taken as indexical to the truth but they must be viewed as nodes in a large network of simultaneous existence of multiple and conflicting narratives afforded by the connective turn of the digital recordings.

This connective turn, by definition, was heightened by social media, too. In media discourse, besides representationality (what a media text means), there is also mediality (what a media text does) (Hoskins \& O'Loughlin, 2010, pp. 26-27). This concept of mediality illuminates why the Binh Thuan riot was often characterized by the anti-Chinese sentiment in the foreign media. Before the riot, there was a Facebook post (Figure 3) opposing the SEAZs law, publicized from a fake account of a famous reporter and game-show host in Vietnam.

Figure 3: A post that opposed the SEAZs law on a fake Facebook account of a famous reporter and game-show host in Vietnam. The post was all about how China could use the SEAZs law to expand and take over Vietnam.

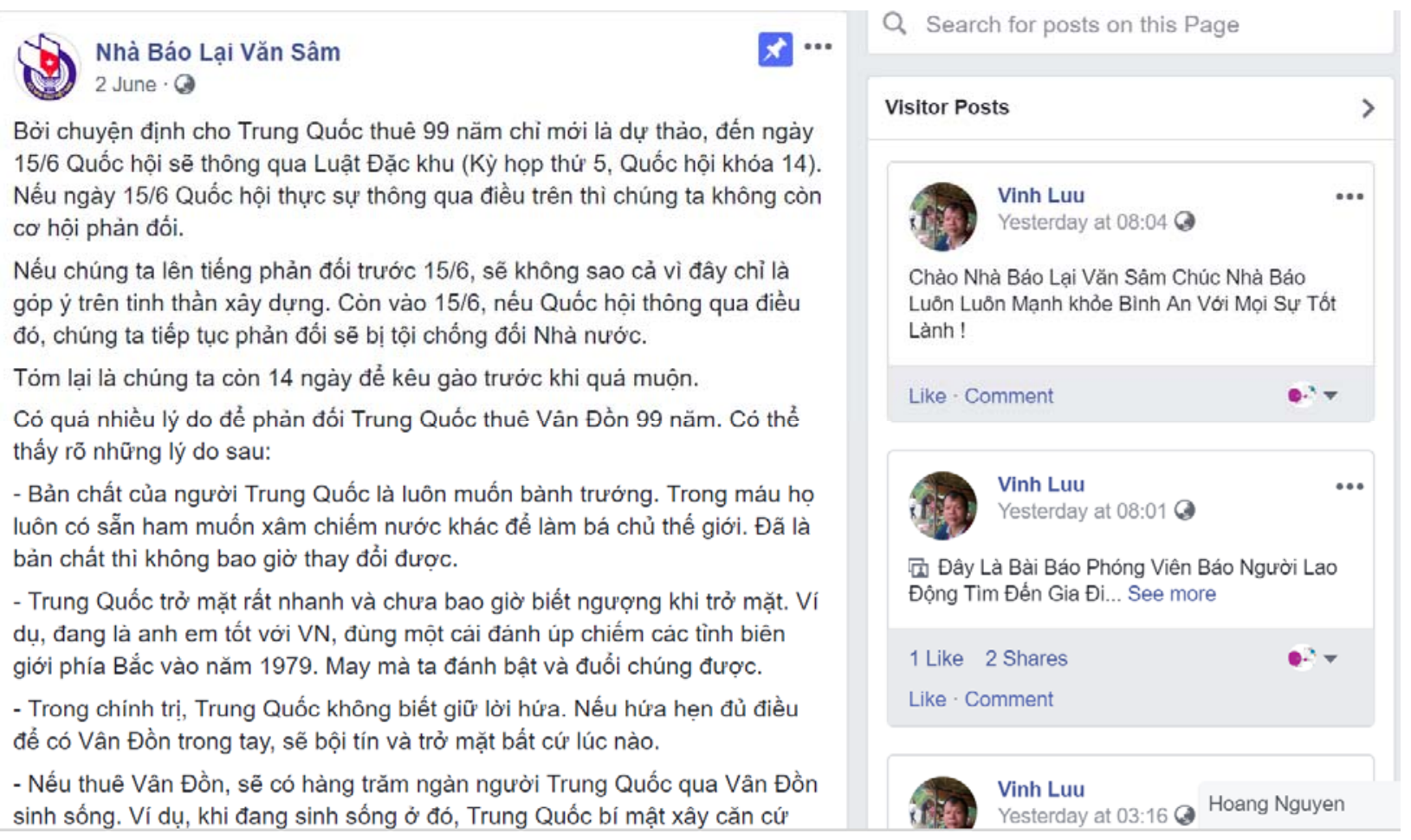

Although the reporter has gone public and disowned the fake account (Chu-Anh, 2018), the post was still circulated by more than 326,000 people and reacted to by more than 178,000 . This is to show how people react to, share, forward, download, like, etc. a media text rarely depends on the truth it represents, but rather on how people form an affective relation with it. In 
this case, the truth of the matter is not important, what makes people share and like the post seems to be the anti-Chinese sentiment and the perceived fact that the post is by a famous person from the government. It is rather ironic that the Vietnamese's anti-Chinese nationalism, which was molded into the people in the process of formal education, was used against the regime. Vietnamese history textbooks are known for its highlights of the country's fights against and victories over Chinese invaders (Nguyen, 2017). Whether the rioters were angry at the Chinese investors or not was still unclear (Panda \& Parameswaran, 2018), what is clear is the anti-China content is effective in attracting shares and likes on social media. In other words, the media coverage of Binh Thuan riot shows just how mediality is central in forming a proper understanding of the event.

Beyond the connective turn and the mediality of the riot is the role of citizen journalism. Hoskins and O'Loughlin (2010, pp. 83) noted how citizen journalism or audiences-as-witness might challenge the status as newsmakers of professional journalists and how this new form of journalism punches holes into the closed and self-perpetrating system of the mass media. As noted by Nguyen and Vuong (2017) and Vuong (2018) in Vietnam, the digital revolution is acting as the foundation for the grassroots foundation for civil society in Vietnam. In the Binh Thuan riot, as most images, videos, even live reports are from Facebook users (BBC Vietnamese, 2018), it seems Vietnamese news consumers could acquire news materials that are "unauthorized, raw, subjective, first-hand, independent, behind-the-scenes, connective, interactive and conversation" in the account of Hoskins and O'Loughlin (2010). Moreover, in this case, the citizen journalists' calls for calmness and how the established media picked up on it (BBC Vietnamese, 2018) show their potential power in influencing the conflicts. It is interesting here that the interactive nature of social media (live stream, live reports, comment, reaction, etc.) has truly enabled "witnessing" according to Peters (2001). To this end, John Durham Peters (2001) described: "To witness is to wish that the record of the past were more whole, and to grasp this lesson now is to live vigilantly, to make the present worthy as we imagine contemplating it from a future viewpoint." It is because of the social media and the availability of digital recording devices that the Vietnamese could participate in a lively conversation as the event unfolds about the right and wrong of the authority's actions, the causes of the situation, and ultimately the fate of their country.

\section{How the state is mediatized}

In analyzing how the Binh Thuan riot was portrayed by the Vietnamese state media and the Vietnamese foreign media, the concept of mediatization is especially relevant. "Mediatization refers to a long-process, whereby social and cultural institutions and modes of interaction are changed because of growing media's influence" (Hjarvard, 2008, pp. 114 as cited in Hoskins and O'Loughlin, 2010).

In this case, how the regime responded to the riot was a sign that it was mediatized. The Vietnamese state has planned for the media fallout of the event: there seems to be an order for the police to only hold their ground and not resort to violence when confronted with the angry crowd (as shown in the Youtube and Facebook videos above). The image of the Vietnamese police force violently and publicly attacking anyone could hurt the state's legitimacy in foreign- 
based media outlets. Besides, the availability of the digital recordings, $84 \%$ of the population use smartphones according to Nielsen Vietnam Smartphone Insights report (VNS, 2017), seems to make the Vietnamese state more cautious in the kind of action that its police force is allowed to engage.

Another way to show the Vietnamese state is mediatized is through the use of words such as "hostile forces," "peaceful evolution," "self-evolution" and "self-transformation." These terminologies are coined by the propaganda and theoretical commission to designate the potential harms that could come to the regime. Hostile forces are any group plotting against the regime; peaceful evolution is about how the hostile forces were plotting against the regime using peaceful means and event; self-evolution and self-transformation are about people losing faith in and turning on the regime as they are exposed to a free flow of information. In the Binh Thuan riot, the state media warned the people not to be enticed and provoked or let their patriotism taken advantages of by the hostile forces. Later, the state media warned against self-evolution and self-transformation. Given how Vietnamese culture is vastly different from Western culture (Vuong et al., 2018), and how culture and history dictate the effectiveness of the media to shape the narrative, it only makes sense that the Vietnamese state media employed its terminologies instead of phrasing the event using the democracy and human rights framework which are dominant in the Western media (Brooten, 2011 \& 2015).

\section{Conclusion \& Discussion}

This study first has explored how the riot in Binh Thuan Province was covered in both Vietnamese state media and the Vietnamese foreign media. It has shown the propaganda and anti-propaganda that takes place on both sides. The state media focuses on the negative outcomes of the riot and its questionable beginning: its starters are addicts and received money to take advantages of people's patriotism; while the foreign media focuses either on the cruelty and the incompetence of the state or the schism between the people and the state.

This study also examines the role played by how citizen journalism and social media. Here, the concepts of the connective turn, mediality, and witness are shown to be crucial in understanding the media fallout of the event. How the media texts related to the riot was shared and reacted in social media was largely determined by the sentiments of the people (mediality) rather than the truth they represent. And because of the connective turn of the digital recordings and the possibility of witnessing the event live on social media, some of the narratives are shown to challenged when new media texts are posted and shared online. These characteristics suggest to get closer to the truth and objectivity; the audiences need to triangulate their sources of news.

This case also exemplifies how the state media, by extension, the state is mediatized. It seems to have prepared for the media fallout of the event and developed it owns terminologies to phrase the event in the way that causes doubts about the narrative on the foreign media. This exemplifies the systematic and standardized responses of the Vietnamese state media and foreign media. The patterns shown in this case will likely to be similar in other unusual socio-political incidents in Vietnam if they arise. The responses, thus, suggest the ideologies on both sides are consistent. When there is a change in the way an incident like this is reported, one can infer that political changes are brewing from within. 


\section{References}

BBC Vietnamese. (2018, June 11). Thu truong cong an vao Binh Thuan [Vice minister of Ministry of Police went to Binh Thuan]. BBC Vietnamese. Retrieved from https://www.bbc.com/vietnamese/vietnam-44438062

Brooten, L. (2011). Media, Militarization, and Human Rights: Comparing Media Reform in the Philippines and Burma. Communication, Culture \& Critique, 4(3), 229-249.

Brooten, L. (2015). Blind Spots in Human Rights Coverage: Framing Violence Against the Rohingya in Myanmar/Burma. Popular Communication, 13(2), 132-144.

Chu-Anh. (2018, June 4). Nha bao Lai Van Sam khang dinh mot lan nua: 100\% trang Facebook mang ten toi deu la gia mao [Journalist Lai Van Sam confirms once more: 100\% Facebook pages with my name are fake]. VTV online. Retrieved from https://vtv.vn/truyen-hinh/nha-bao-lai-van-sam-khang-dinh-lan-nua-100-trang-facebookmang-ten-toi-deu-la-gia-mao-20180604100531065.htm

Duc Trong. (2018, June 10). Doan nguoi qua khich tran vao tru so ubnd tinh binh thuan [the provoked crowd stormed in the People's Committee Headquarter]. Tuoi tre. Retrieved from https://tuoitre.vn/doan-nguoi-qua-khich-tran-vao-tru-so-ubnd-tinh-binh-thuan20180610212701884.htm

Hayton, B. (2010). Vietnam: rising dragon. New Haven, Connecticut: Yale University Press.

Hjarvard, S. (2008). The mediatization of society. Nordicom Review, 29(2), 102-131.

Hoskins, A., \& O'Loughlin, B. (2010). War and media. Polity.

Le-Huan. (2018, June 11). Bac thong tin co thuong vong trong vu qua khich o Binh Thuan [Refuting the reporting of causalities in the Binh Thuan incident]. Vietnamnet. Retrieved from http://vietnamnet.vn/vn/thoi-su/bac-thong-tin-co-thuong-vong-trong-vu-qua-khicho-binh-thuan-456038.html

Luong-Bang. (2018, July 15). Nha dau tu Trung Quoc lam bao nhieu du an nhiet dien o Vietnam [How many thermal power plants do Chinese investors do in Vietnam]. Dan Tri. Retrieved from http://dantri.com.vn/su-kien/nha-dau-tu-trung-quoc-lam-bao-nhieu-du-annhiet-dien-o-viet-nam-20180713063056359.htm

Nguoi-Viet. (2018, June 11). Biểu tình, đình công tiếp diễn ở Bình Thuận, Sài Gòn: Hơn 200 người bị bắt [Protests and Strikes continue in Binh Thuan, Sai Gon: More than 200 people arrested]. Nguoi Viet. Retrieved from: https://www.nguoi-viet.com/tin-chinh/baoloan-bieu-tinh-dinh-cong-tiep-dien-o-binh-thuan-sai-gon-hon-200-nguoi-bi-bat/

Nguyen, P. M. \& Vuong, Q. H. (2016). In Vietnam, digital is democratizing. CIMA-NED, November 14, 2016. Retrieved from: http://www.cima.ned.org/blog/vietnam-digitaldemocratizing/ 
Nguyen, N. H. T. (2017). Anti-Chinese Sentiment in Contemporary Vietnam: Constructing Nationalism, New Democracy, and the Use of "the Other". Undergraduate Student Research Awards. 40.

Panda, A. \& Parameswaran, P. (2018, June 26). The Geopolitical Significance of Anti-China Protests in Vietnam. The Diplomat. Retrieved from https://thediplomat.com/2018/06/thegeopolitical-significance-of-anti-china-protests-in-vietnam/

Peters, J. D. (2001). Witnessing. Media Culture Society, 23: 707.

Phuong-Nghi. (2018, June 11). Vu hang tram nguoi dap pha tru so UBND tinh Binh Thuan: "Rat kinh hoang, khong ai tuong tuong duoc." [Hundreds of people destroyed Binh Thuan province's People's Council building: "Unimaginable"]. Soha. Retrieved from http://soha.vn/binh-thuan-hop-bao-ve-vu-hang-tram-nguoi-tu-tap-gay-roi-dap-pha-tru-soubnd-tinh-20180611143651265.htm

RFA. (2015, April 16). Vi sao nguoi dan Binh Thuan bieu tinh phan doi nha may dien? [Why do Binh Thuan people protest against the power plant?]. RFA. Retrieved from https://www.rfa.org/vietnamese/news/reportfromvn/binh-th-protest-pw-plant$\underline{04162015054158 . h t m l}$

Sands, G. (2018, June 12). In Vietnam, Protests Highlight Anti-Chinese Sentiment. The Diplomat. Retrieved from https://thediplomat.com/2018/06/in-vietnam-protestshighlight-anti-chinese-sentiment/

VNS. (2017, November 29). Smartphone users cover $84 \%$ of VN population. Viet Nam News. Retrieved from http://vietnamnews.vn/economy/418482/smartphone-users-cover-84-ofvn-population.html\#GJz8V2GAFTuK23gL.99

VOA Vietnamese. (2018, June 11). Binh Thuan: Dan canh bao 'lai bieu tinh' neu cong an 'truy bat' [People warned they would 'protest' against if the police kept 'prosecuting']. VOA Vietnamese. Retrieved from https://www.bbc.com/vietnamese/vietnam-44438062

Vuong, Q. H. (2014). Vietnam's political economy: a discussion on the 1986-2016 period. WPCEB $N^{\circ} 14-010$. Universite Libre de Bruxelles.

Vuong, Q. H. (2018). The Internet and the grassroots foundation of civil society in Indochina. Working Papers CEB 18-027, ULB - Université Libre de Bruxelles.

Vuong, Q. H., \& Tran, T. D. (2009). The Cultural Dimensions of the Vietnamese Private Entrepreneurship. The IUP Journal of Entrepreneurship Development, VI(3-4), 54-78.

Vuong, Q. H., Bui, Q.K., La, V.P., Vuong, T. T., Nguyen, V. H., Ho, M. T., Nguyen, T. H. K., Ho, M. T. (2018). Cultural additivity: Behavioural insights from the interaction of Confucianism, Buddhism, and Taoism in folktales. Palgrave Communications, 4, 143. DOI: https://doi.org/10.1057/s41599-018-0189-2. 